Article

\title{
Emission Ratios of the Tropospheric Ozone Precursors Nitrogen Dioxide and Formaldehyde from Australia's Black Saturday Fires
}

\section{Emma Young ${ }^{\dagger}$ and Clare Paton-Walsh *}

School of Chemistry, University of Wollongong, Northfields Ave, NSW 2522, Australia

$\dagger$ Present address: Australian Nuclear Science and Technology Organisation, NSW 2232, Australia; E-Mail: emma.young@ansto.gov.au.

* Author to whom correspondence should be addressed; E-Mail: clarem@uow.edu.au; Tel.: +61-2-4221-5065; Fax: +61-2-4221-4287.

Received: 5 September 2011; in revised form: 19 October 2011 / Accepted: 19 October 2011 / Published: 31 October 2011

\begin{abstract}
The 'Black Saturday' fires were a series of devastating forest fires that burned across Victoria, Australia, during February and March of 2009. In this study we have used satellite data made publically available by NASA from the Ozone Monitoring Instrument (OMI) and the Atmospheric InfraRed Sounder (AIRS) to track the smoke plume from the Black Saturday firestorm and explore the chemical aging of the smoke plume in the first days after emission. We also determined emission ratios for formaldehyde and nitrogen dioxide within smoke from fires actively burning across Victoria between 7 and 17 February 2009. The mean emission ratios with respect to carbon monoxide derived for these two tropospheric ozone precursors are $\left(0.016 \pm 0.004 \mathrm{~mol}_{\mathrm{mol}}^{-1}\right)$ for formaldehyde and $\left(0.005 \pm 0.002 \mathrm{~mol}^{\mathrm{mol}}{ }^{-1}\right)$ for nitrogen dioxide. The mean emission ratio for formaldehyde with respect to $\mathrm{CO}$ is in broad agreement with values previously quoted in the literature for temperate forest fires. However, to our knowledge there are no previous measurements of emission ratios for nitrogen dioxide from Australian temperate forest fires.
\end{abstract}

Keywords: fires; emissions; biomass burning; formaldehyde; nitrogen dioxide; carbon monoxide; smoke aging; AIRS; OMI; Black Saturday 


\section{Introduction}

Biomass burning releases trace gases and aerosol particles into the atmosphere with consequences for atmospheric chemistry and climate. Trace gases emitted by vegetation fires include greenhouse gases, precursors to greenhouse gases, and precursors to tropospheric ozone formation [1-4]. Several of the trace gases emitted by biomass burning can influence the acidity of precipitation $[1,5]$ and both trace gases and aerosols can degrade air quality and pose a threat to human health [6]. Aerosols can also affect the transfer of radiation in the atmosphere directly by absorbing or scattering radiation or indirectly as cloud condensation nuclei $[1,6]$.

Emission ratios of nitrogen dioxide $\left(\mathrm{NO}_{2}\right)$ and formaldehyde $\left(\mathrm{H}_{2} \mathrm{CO}\right)$ are important because of their role in the formation of tropospheric ozone. Tropospheric ozone is a major pollutant and powerful respiratory irritant, with detrimental effects on human health in urban environments [7]. In situ photochemical production of ozone is achieved via the multi-step photo-oxidation of organic molecules and accounts for approximately half of the global source of tropospheric ozone. The essential starting ingredients for this process are hydrocarbons and volatile organic compounds (including $\mathrm{H}_{2} \mathrm{CO}$ ), nitrogen oxides $\left(\mathrm{NO}+\mathrm{NO}_{2}\right)$ and $\mathrm{UV}$ radiation. Carbon monoxide $(\mathrm{CO})$ and $\mathrm{H}_{2} \mathrm{CO}$ are intermediates in the process and their oxidation also produces ozone. $\mathrm{H}_{2} \mathrm{CO}$ 's role as a key intermediate means that it has been used successfully to constrain the local emissions of volatile organic compounds [8]. In the Southern Hemisphere there are fewer industrial sources than in the Northern Hemisphere and thus the relative importance of biomass burning as a source of these precursor gases is larger. Thus combined knowledge of the emission ratios of $\mathrm{H}_{2} \mathrm{CO}$ and $\mathrm{NO}_{2}$ from Australian vegetation fires provides the main drivers for tropospheric ozone formation in the region.

It has been estimated that Australia contributes $7-8 \%$ of the total carbon emissions from global biomass burning [9]. Whilst emissions from Australian savanna fires are well documented in the literature [10-13], emissions from Australian forest fires have received less attention. Studies by Paton-Walsh et al. [14-17] have used ground-based remote sensing to derive estimates of emissions of some trace gases from typical Australian forest fires including $\mathrm{H}_{2} \mathrm{CO}$, hydrogen cyanide, methanol, ammonia, formic acid and some hydrocarbons. However, emissions of $\mathrm{NO}_{2}$ from Australian forest fires are not yet represented in emissions inventories. It is important to gather information on the emissions from Australian biomass burning in order to understand the role that the continent plays in global atmospheric chemistry and to accurately predict its future contribution.

On Saturday 7 February 2009 (a date now known in Australia as 'Black Saturday'), at least 400 individual fires were ignited (by lightning and arson) in the southeastern Australian state of Victoria, which continued to burn throughout the state until mid-March. Smoke emitted by the fires was observed by numerous satellite-based sensors, including ACE, MLS, OMI and OSIRIS [18,19]. In this study satellite data made publically available by NASA is used to determine emission ratios for $\mathrm{H}_{2} \mathrm{CO}$ and $\mathrm{NO}_{2}$ with respect to $\mathrm{CO}$ within the smoke from the Black Saturday fires. Descriptions of the satellite platforms and sensors used are given below.

Aqua and Aura are two of a series of satellites known as the A-Train, orbiting in a sun-synchronous near-polar orbit around the Earth. The satellites of the A-Train orbit at an altitude of $705 \mathrm{~km}$ and an inclination of approximately 98 degrees. Each satellite completes 14.55 orbits per day with each successive orbit separated by 24.7 degrees longitude at the equator due to the rotation of the Earth. The 
flight formation of the A-Train means that each satellite instrument within the formation views the same area over the Earth within about 15 minutes of any of the other satellite instruments; this is approximately the amount of time by which Aura lags Aqua [20].

The Ozone Monitoring Instrument (OMI) is carried onboard Aura and consists of two grating spectrometers that record daily global measurements of solar radiation backscattered from the Earth and the Earth's atmosphere in the wavelength range of $270-500 \mathrm{~nm}$ with a spatial resolution of $13 \times 24 \mathrm{~km}$ in global mode [21]. From this information OMI determines column amounts of trace gases including $\mathrm{H}_{2} \mathrm{CO}$ (measured at spectral resolution of $0.45 \mathrm{~nm}$ in the UV-2: $310-365 \mathrm{~nm}$ ) and $\mathrm{NO}_{2}$ (measured at spectral resolution of $0.63 \mathrm{~nm}$ in the visible: $350-500 \mathrm{~nm}$ ) [22]. The column amount of a gas is the number of molecules of the gas in a square centimetre column extending from the Earth's surface to the top of the atmosphere.

Comparisons of $\mathrm{OMI} \mathrm{H}_{2} \mathrm{CO}$ to aircraft measurements of $\mathrm{H}_{2} \mathrm{CO}$ show good agreement at background levels - however a $17 \%$ negative bias in $\mathrm{OMI}_{2} \mathrm{CO}$ total columns is observed for higher $\mathrm{H}_{2} \mathrm{CO}$ values (above $5 \times 10^{15}$ molecules $\mathrm{cm}^{-2}$ ) [23]. Validation of $\mathrm{OMI} \mathrm{NO}_{2}$ in near cloud free conditions has shown good agreement with ground-based measurements [24], however there is evidence from comparisons with high resolution retrievals that operational products are biased high by as much as $30 \%$ in remote areas partially as a result of coarse resolution of albedo, terrain pressure and a priori profile assumptions [25]. In this study Level 2 operational data products from OMI were used and thus these biases will feed through into the uncertainty of the derived emission ratios.

OMI Ultra-Violet Aerosol Index is also used qualitatively in this study to help to identify the regions affected by smoke from the Black Saturday fires. UV Aerosol Index is an empirical measure of the presence of UV-absorbing aerosols such as carbonaceous aerosols from biomass burning, desert dust or volcanic ash. It is a logarithmic expression of the ratio of observed over calculated intensity at $354 \mathrm{~nm}$ [26]. The value of UV Aerosol Index increases with the altitude of the absorbing aerosols and is less affected by cloud interference than aerosol optical depth.

The Atmospheric Infrared Sounder (AIRS) is an infrared spectrometer onboard the satellite Aqua that measures the Earth's outgoing radiation in the wavelength ranges of $0.4-1.0 \mu \mathrm{m}$ (visible) and 3.7-15.4 $\mu \mathrm{m}$ (infrared), separating wavelengths that are sensitive to different species including water vapour and some trace gases[27]. AIRS has an infrared spatial resolution of $13.5 \mathrm{~km}$ at nadir and provides measurements that contribute to a daily level 3 gridded $\mathrm{CO}$ column amount data product with one degree by one degree spatial resolution. Comparisons to aircraft measurements show agreement nearing the target accuracy for AIRS of $15 \%$ [28].

With a swath width of $1650 \mathrm{~km}$ AIRS achieves almost global coverage twice a day[27] OMI has a swath width of $2594 \mathrm{~km}$ and is also capable of almost daily global coverage[21]. The instrument swaths do not overlap at all latitudes, so some areas are not scanned daily but are eventually covered within subsequent days. In this study only data with values within the swaths of both AIRS and OMI are used.

A number of previous studies have used satellite-based measurements of $\mathrm{H}_{2} \mathrm{CO}$ to constrain biogenic isoprene emissions [8,29] (including the use of $\mathrm{OMI} \mathrm{H}_{2} \mathrm{CO}$ [30]) or $\mathrm{CO}$ to constrain the total emissions from biomass burning sources [31] (including studies that used AIRS CO measurements [32,33]). 
Mebust et al [34] used OMI tropospheric $\mathrm{NO}_{2}$ in conjunction with Fire Radiative Power from the MODIS instrument to characterize the emissions of $\mathrm{NO}_{2}$ from different vegetation fires in California and Nevada, but satellite-based measurements of smoke plumes are still an under-utilized resource for characterizing emissions from data poor regions of the Southern Hemisphere.

In south eastern Australian forests the fuel source is predominantly varieties of Eucalyptus tree. These trees are adapted for fire and can survive repeated lower intensity burning. For this reason it is not clear that the emissions that result from such low intensity fires (that burn mainly in the understory) will be the same as the emissions that result from huge firestorms like those of Black Saturday. For practical reasons most measurements of emission ratios come from prescribed burns that are typically low intensity burns lit intentionally in order to reduce the fuels loads. Thus the satellitebased sensor measurements of emission ratios from the Black Saturday fires are particularly interesting because they provide a means of characterising the emissions from the most intense wildfires.

\section{Deriving Emission Ratios from OMI and AIRS Data}

Daily total column amounts of $\mathrm{H}_{2} \mathrm{CO}, \mathrm{NO}_{2}$ and $\mathrm{CO}$ as well as maps visualizing these daily data products and OMI UV Aerosol Index [26] were downloaded from the Giovanni online data system [35]. The daily mapped column amounts for the reference gas, $\mathrm{CO}$, were used in conjunction with MODIS thermal anomalies [36] and OMI UV Aerosol Index to define the region of the active fires. By limiting analyses to areas where CO and UV Aerosol Index were visibly enhanced on each individual day over the region of the active fires shown by MODIS thermal anomalies, $\mathrm{CO}$ emissions from the fires could be clearly distinguished from other sources of CO.

Use of $1^{\circ}$ latitude by $1^{\circ}$ longitude gridded products allowed the different satellite products to be matched on a horizontal grid-however differences in their sensitivities, resolution and the approximately 15 minutes time lapse between Aura and Aqua all introduce errors in the sampling overlap. For total column amount $\mathrm{CO}$ only a single value was available per grid space, however, for the total column amounts of $\mathrm{H}_{2} \mathrm{CO}$ and $\mathrm{NO}_{2}$ up to 16 individual retrievals were averaged per grid space. Due to missing data points typically only 8-12 points were included in the averages and the mean values were weighted in the regression analysis by the square root of the number of points available.

The uncertainties given for the $\mathrm{NO}_{2}$ total column amount data are derived by assuming an error of $50 \%$ for $\mathrm{OMI} \mathrm{NO}_{2}$ total column amount retrievals in the presence of pollution and clouds [37], then dividing by the square root of the number of data points averaged. Uncertainties of $25 \%$ have been reported for $\mathrm{OMI} \mathrm{H}_{2} \mathrm{CO}$ total column amount measurements under biogenically enhanced conditions [38], however for the heavily polluted conditions of the smoke measurements used in this work the uncertainties may be greater and so a value of 50\% was assumed, as for the $\mathrm{NO}_{2}$ retrievals.

Mean total column amounts of $\mathrm{H}_{2} \mathrm{CO}$ and $\mathrm{NO}_{2}$ from 7 to 17 February 2009 for each grid space $\left(1^{\circ}\right.$ latitude by $1^{\circ}$ longitude) in the defined areas were plotted against the co-located total column amounts of $\mathrm{CO}$. The gradient of the best straight line fit (using a linear least squares regression) to these points, yields the emission ratio of each gas relative to $\mathrm{CO}$. 
The CO column amounts from 7 February showed insufficient enhancements for any emission ratios to be determined with respect to $\mathrm{CO}$, probably because the smoke plume had yet to develop strongly at the time of the satellite overpass on 7 February, as most of the major fires had only just begun on this day. There were significantly enhanced concentrations of $\mathrm{CO}, \mathrm{H}_{2} \mathrm{CO}$ and $\mathrm{NO}_{2}$ over the active fire region on 8 February 2009. Data from this day yielded well correlated emission ratios with respect to CO (as previously reported at the Australian Meteorological and Oceanographic Society meeting [39]). There appeared to be a significant fraction of OMI data missing over the relevant areas on $9,10,11$ and 14 February 2009 , leading to increased uncertainties when averaging over the $1^{\circ}$ latitude by $1^{\circ}$ longitude grid spaces. Missing data occurs when the retrievals have been rejected by the processing algorithm for a variety of reasons. Significant cloud interference is likely to have contributed to the large amount of missing data on these days. The $\mathrm{OMI} \mathrm{H}_{2} \mathrm{CO}$ and $\mathrm{NO}_{2}$ data that was available over the region on these days was poorly correlated with AIRS CO total columns. There was also a significant fraction of AIRS data missing on 12 February 2009 where the instrument could not retrieve $\mathrm{CO}$ total column amount data, so no emission ratios with respect to $\mathrm{CO}$ were determined for these days. Column amounts of $\mathrm{H}_{2} \mathrm{CO}, \mathrm{NO}_{2}$ and $\mathrm{CO}$ were enhanced over the regions of the active fires on 13, 15, 16 and 17 February 2009 and there were no significant parts of the data missing. OMI total column amounts of $\mathrm{H}_{2} \mathrm{CO}$ and $\mathrm{NO}_{2}$ from these days (and 8 February 2009) at the time of the Aura satellite overpass are plotted against the co-located AIRS CO measured approximately 15 minutes earlier (at the time of the Aqua satellite overpass) - see Figure 1. The gradients of these plots (and their standard deviations) form daily estimates of the emission ratios and are shown in Table 1. Also shown are the mean values from the five days which we take as our best estimates for the emission ratios of $\mathrm{H}_{2} \mathrm{CO}$ and $\mathrm{NO}_{2}$ with respect to $\mathrm{CO}$ from the Black Saturday fires.

Table 1. Emission ratios of $\mathrm{H}_{2} \mathrm{CO}$ and $\mathrm{NO}_{2}$ with respect to $\mathrm{CO}$ in smoke from the active Victorian fires including correlation coefficients from each linear regression analysis ${ }^{\mathrm{a}}$.

\begin{tabular}{ccccc}
\hline \multirow{2}{*}{ Date } & ER & $\mathbf{H}_{\mathbf{2}} \mathbf{C O}$ & $\mathbf{\text { NO }}$ \\
\cline { 2 - 5 } & $\mathbf{E R}$ & $\mathbf{R}^{\mathbf{2}}$ \\
\hline 8 Feb. 2009 & $0.017 \pm 0.004$ & 0.66 & $0.004 \pm 0.001$ & 0.65 \\
13 Feb. 2009 & $0.020 \pm 0.003$ & 0.88 & $0.008 \pm 0.002$ & 0.82 \\
15 Feb. 2009 & $0.010 \pm 0.004$ & 0.44 & $0.005 \pm 0.002$ & 0.57 \\
16 Feb. 2009 & $0.014 \pm 0.005$ & 0.52 & $0.004 \pm 0.002$ & 0.47 \\
17 Feb. 2009 & $0.017 \pm 0.005$ & 0.72 & $0.004 \pm 0.001$ & 0.75 \\
\hline Mean ER & \multicolumn{2}{c}{$0.016 \pm 0.004$} & \multicolumn{2}{c}{$0.005 \pm 0.002$} \\
\hline
\end{tabular}

${ }^{\text {a }}$ Here $E R$ represents the emission ratio of each trace gas with respect to $\mathrm{CO}$; $R^{2}$ represents the square of the correlation coefficient of the linear regression performed to obtain each emission ratio; Mean ER is the average of the emission ratios obtained for the days listed for each trace gas. The standard deviation of the emission ratios calculated for each day was taken as the uncertainty of the mean emission ratio. 
Figure 1. OMI total column amounts of (a) $\mathrm{H}_{2} \mathrm{CO}$ and (b) $\mathrm{NO}_{2}$ plotted against coincident AIRS CO total column amount measurements within smoke from the active Victorian fires on various days during February 2009. Each point on the plots corresponds to an average total column amount for a particular $1^{\circ}$ latitude by $1^{\circ}$ longitude grid space over Victoria.

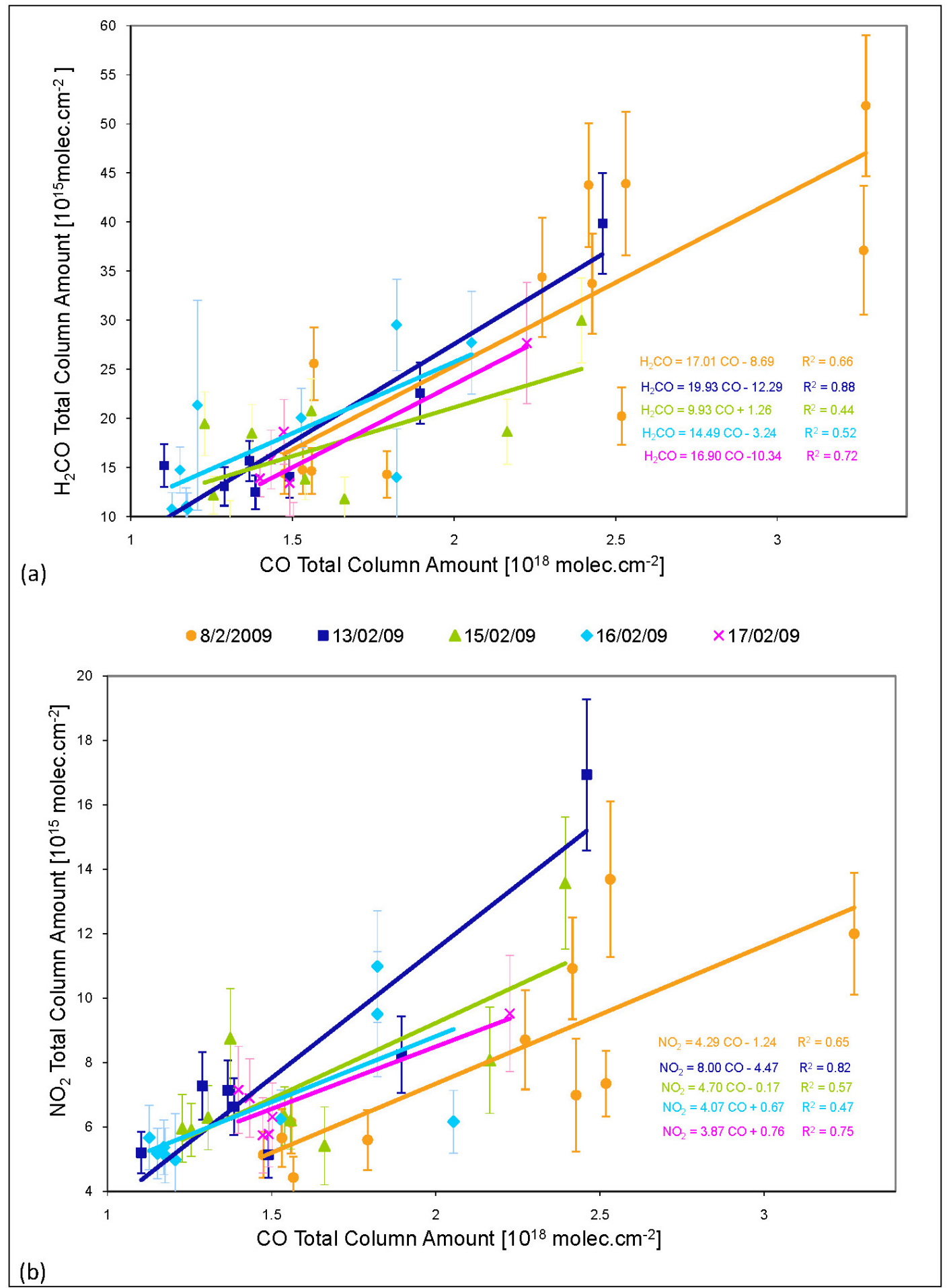




\section{Discussion of Derived Emission Ratios}

The mean emission ratio derived in this work for $\mathrm{H}_{2} \mathrm{CO}$ with respect to $\mathrm{CO}$ of $0.016 \pm 0.004$ is in broad agreement with the two previous published values for Australian forest fires $(0.019 \pm 0.008$ [14] and $0.023 \pm 0.007$ [15]). By using the relevant emission factor for $\mathrm{CO}$, the results may also be compared to emission factors given in the review papers by Andreae and Merlet [40] and Akagi et al. [41] that form the basis of inventories used by chemical transport models. Our emission ratio yields an emission factor for $\mathrm{H}_{2} \mathrm{CO}$ of $1.8 \pm 0.5 \mathrm{~g} \mathrm{~kg}^{-1}$ comparable to Andreae and Merlet's $2.2 \pm 0.5 \mathrm{~g} \mathrm{~kg}^{-1}$ for extra-tropical forests using their value of $107 \pm 37 \mathrm{~g} \mathrm{CO}$ per kg dry fuel burned [40]. Similarly, using Akagi et al. CO emission factor of $122 \mathrm{~g} \mathrm{~kg}^{-1}$ and our emission ratio for $\mathrm{H}_{2} \mathrm{CO}$ gives $2.1 \pm 0.5 \mathrm{~g} \mathrm{~kg}^{-1}$ in good agreement with their value of $1.92 \mathrm{~g} \mathrm{~kg}^{-1}$ for $\mathrm{H}_{2} \mathrm{CO}$ from extra-tropical forests [41].

The emission ratio derived for $\mathrm{NO}_{2}$ with respect to $\mathrm{CO}$ in this work $(0.005 \pm 0.002)$ is, to our knowledge, the first emission ratio for $\mathrm{NO}_{2}$ from Australian temperate forest fires. $\mathrm{NO}_{2}$ is highly reactive and results for different types of vegetation and in different climatic regions of the world can vary by several orders of magnitude. This inconsistency of results is a combination of natural variability (caused by different vegetation types, climatic conditions and type of combustion) and the uncertainties inherent in the different measurement techniques used.

Combining the emission ratio from this study with the $\mathrm{CO}$ emission factors for extra-tropical forests gives $0.9 \pm 0.3 \mathrm{~g} \mathrm{NO}_{2} \mathrm{~kg}^{-1}$ using Andreae and Merlet's $107 \pm 37 \mathrm{~g} \mathrm{CO} \mathrm{kg}^{-1}$ and $1.0 \pm 0.4 \mathrm{~g} \mathrm{NO}_{2} \mathrm{~kg}^{-1}$ using Akagi et al. $122 \mathrm{~g} \mathrm{CO} \mathrm{kg}^{-1}$ [40,41]. However, if we follow the more usual convention of expressing $\mathrm{NO}_{\mathrm{x}}$ as $\mathrm{NO}$ in the conversion to an emission factor we get $0.6 \pm 0.2 \mathrm{~g} \mathrm{~kg}^{-1}$ and $0.7 \pm 0.3 \mathrm{~g} \mathrm{~kg}^{-1}$ of $\mathrm{NO}_{2}$ expressed as $\mathrm{NO}$ using Andreae and Merlet's and Akagi et al. $\mathrm{CO}$ emission factors respectively) [40,41]. Assuming that typically $75 \%$ of the $\mathrm{NO}_{\mathrm{x}}$ in the smoke is in the form of $\mathrm{NO}_{2}[42,43]$, our values are significantly lower than Andreae and Merlet's equivalent value for $\mathrm{NO}_{\mathrm{x}}$ from extra-tropical forests of $3.0 \pm 1.4 \mathrm{~g} \mathrm{~kg}^{-1}$ but in better agreement with more recent values such as Akagi et al. $1.22 \mathrm{~g} \mathrm{~kg}^{-1}$ or Alvarado et al. $1.06 \mathrm{~g} \mathrm{~kg}^{-1}$ [41,44]. Interestingly it is in excellent agreement with Mebust et al. $0.59 \pm 0.16 \mathrm{~g} \mathrm{~kg}^{-1} \mathrm{NO}_{2}$ as $\mathrm{NO}$ from forest fires over California and Nevada which also used $\mathrm{OMI} \mathrm{NO}_{2}$ measurements [34].

\section{Chemical Aging of the Smoke from Australia's Black Saturday Fires}

The maps of OMI UV Aerosol Index showed that the smoke plume from the huge firestorm on Black Saturday (7 February 2009) separated from subsequent emissions and persisted for several weeks, providing the opportunity to track the chemical aging of the smoke plume. In this study we attempt to do this by deriving ratios of $\mathrm{H}_{2} \mathrm{CO}$ and $\mathrm{NO}_{2}$ to carbon monoxide as the smoke ages over the first 2-3 days. The total column amounts of $\mathrm{H}_{2} \mathrm{CO}$ and $\mathrm{NO}_{2}$ derived from $\mathrm{OMI}$ spectra over the region of the smoke plume showed no significant enhancements after 10 February 2009. This is because $\mathrm{H}_{2} \mathrm{CO}$ and $\mathrm{NO}_{2}$ are highly reactive with atmospheric lifetimes of the order of hours [45]. In comparison $\mathrm{CO}$ has a lifetime in the order of 2 months [46] and so changes in the ratio of $\mathrm{H}_{2} \mathrm{CO}$ and $\mathrm{NO}_{2}$ with respect to $\mathrm{CO}$ as the smoke ages will be dominated by the rapid changes in the more reactive gases.

Measurements of other longer- lived species (e.g., $\mathrm{C}_{2} \mathrm{H}_{6}$ and $\mathrm{HCN}$ from the IASI and ACE satellite sensors) exist and could be used to further elucidate smoke aging in this and other cases, but are not 
yet publically available and so are not included in this study. We found that OMI UV Aerosol Index [26] was an excellent product for tracking smoke plumes because gaps in the data are far rarer than for other products that we tried (such as aerosol optical depth or different trace gas products) that are badly affected by cloud interference.

Figure 2(a) shows OMI UV Aerosol Index data from $33^{\circ} \mathrm{S}, 144^{\circ} \mathrm{E}$ to $51^{\circ} \mathrm{S}, 170^{\circ} \mathrm{W}$ revealing the location of the Black Saturday smoke plume on 8 February 2009. Gaps in the UV Aerosol Index data to the edge of each satellite swath on 8 February 2009 artificially break up the plume into three areas, one that is close to and incorporates the active fire region, the main section that extends across the south island of New Zealand and a small region to the east of New Zealand. The first two areas are clearly visible in the $\mathrm{OMI} \mathrm{H}_{2} \mathrm{CO}$ column amounts (see Figure 2(b)) although the third area is less clear. Figure 2(c) shows the $\mathrm{OMI} \mathrm{NO}_{2}$ total column amounts with clear enhancements visible in the first area and small areas of enhancements visible in the other two areas. Large areas of missing data indicate that much of the data may have been rejected by the algorithm and this may be the result of interference in the signal from the smoke aerosols [24].

Figure 2. Images representing the travelling plume from Black Saturday from $33^{\circ} \mathrm{S}, 144^{\circ} \mathrm{E}$ to $51^{\circ} \mathrm{S}, 170^{\circ} \mathrm{W}$ on 8 February 2009 using (a) OMI UV aerosol index, (b) $\mathrm{OMI} \mathrm{H}_{2} \mathrm{CO}$ total column amount $\left(\times 10^{15}\right.$ molecules.cm $\left.{ }^{-2}\right)$, (c) $\mathrm{OMI} \mathrm{NO}_{2}$ total column amount $\left(\times 10^{15}\right.$ molecules.cm $\left.{ }^{-2}\right)$ and $(\mathbf{d})$ AIRS CO total column amount $\left(\times 10^{18}\right.$ molecules.cm $\left.{ }^{-2}\right)$.
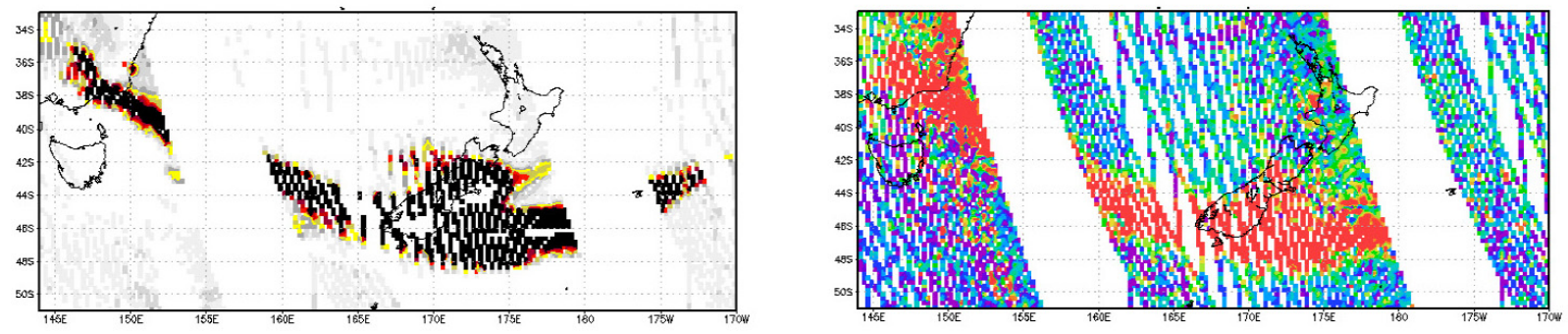

(a)
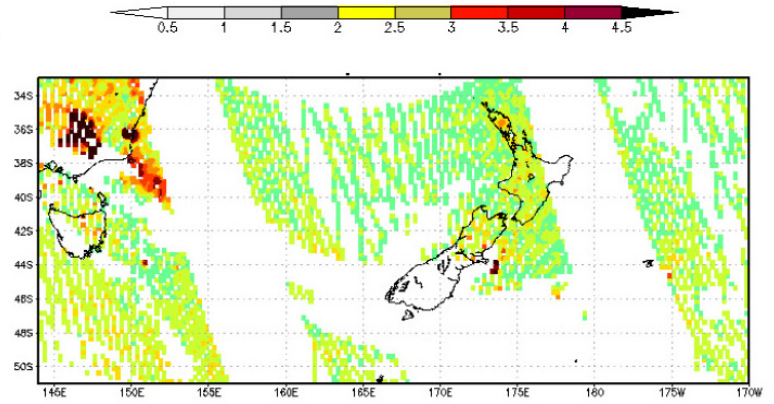

(b)

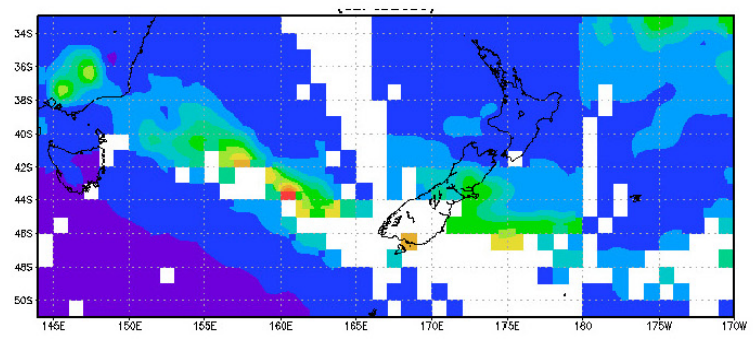

(c)

(d)

Figures 3 and 4 show that on 9 and 10 February 2009, the smoke plume was located to the northeast of New Zealand's north island. Enhancements are clearly visible in the OMI UV Aerosol Index and in the AIRS CO total column amounts on 10 February 2009, whilst the plume is hard to see clearly in the other products as early as 9 February 2009. 
Back trajectory analysis plots produced using the British Atmospheric Data Centre online service [47] were used to estimate the age of the smoke measured by the satellite sensors in the first two regions on 8 February 2009 ( $4 \pm 4$ hours and $19 \pm 5$ hours respectively) and on 9 February 2009 (36 \pm 6 hours) and 10 February 2009 (60 \pm 6 hours). The gradients of plots of $\mathrm{OMI} \mathrm{H}_{2} \mathrm{CO}$ and $\mathrm{NO}_{2}$ total columns against AIRS CO total column yielded normalized excess mixing ratios (which are equivalent to emission ratios but for aged smoke) [41] for each of the regions of the travelling plume described above and plotted against the estimated age of the smoke (see Figure 5). (Note that these normalized excess mixing ratios go to zero at background levels since they represent the excess concentration of the trace gas divided by the excess concentration of carbon monoxide).

Figure 3. Images representing the travelling plume from Black Saturday from $15^{\circ} \mathrm{S}, 170^{\circ} \mathrm{E}$ to $45^{\circ} \mathrm{S}, 140^{\circ} \mathrm{W}$ on 9 February 2009 using (a) OMI UV aerosol index, (b) $\mathrm{OMI} \mathrm{H}_{2} \mathrm{CO}$ total column amount $\left(\times 10^{15}\right.$ molecules.cm $\left.{ }^{-2}\right)$, (c) $\mathrm{OMI} \mathrm{NO}_{2}$ total column amount $\left(\times 10^{15}\right.$ molecules.cm $\left.{ }^{-2}\right)$ and $(\mathbf{d})$ AIRS CO total column amount $\left(\times 10^{18}\right.$ molecules.cm $\left.{ }^{-2}\right)$.
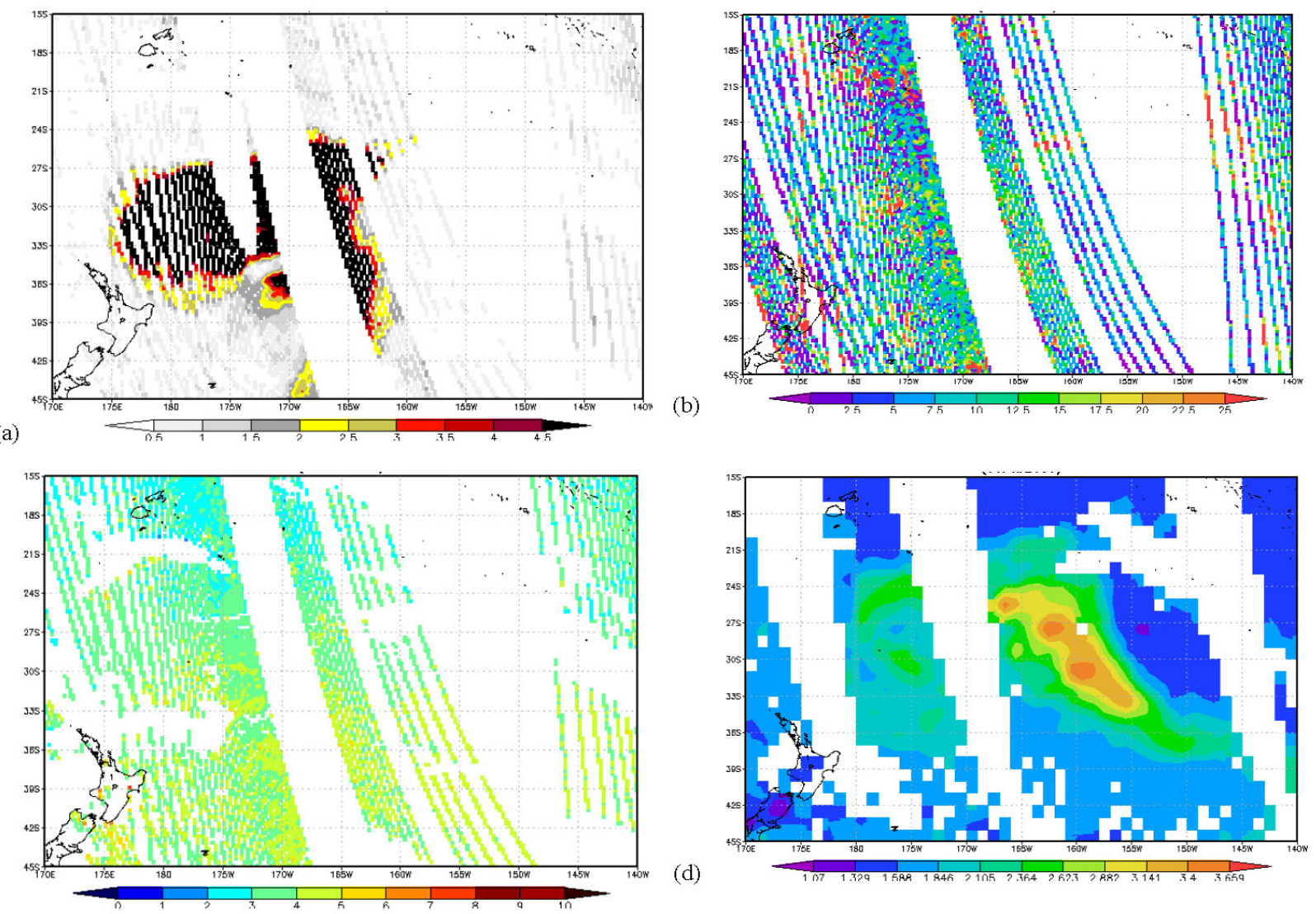
Figure 4. Images representing the travelling plume from Black Saturday from $10^{\circ} \mathrm{S}, 165^{\circ} \mathrm{E}$ to $45^{\circ} \mathrm{S}, 156^{\circ} \mathrm{W}$ on 10 February 2009 using (a) OMI UV aerosol index, (b) OMI $\mathrm{H}_{2} \mathrm{CO}$ total column amount $\left(\times 10^{15}\right.$ molecules.cm $\left.{ }^{-2}\right)$, (c) $\mathrm{OMI} \mathrm{NO}_{2}$ total column amount $\left(\times 10^{15}\right.$ molecules.cm $\left.{ }^{-2}\right)$ and (d) AIRS CO total column amount $\left(\times 10^{18}\right.$ molecules.cm $\left.{ }^{-2}\right)$.

(a)

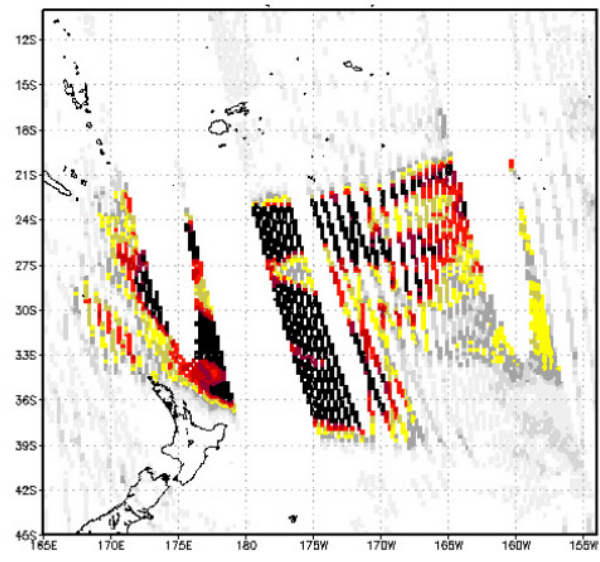

(c)

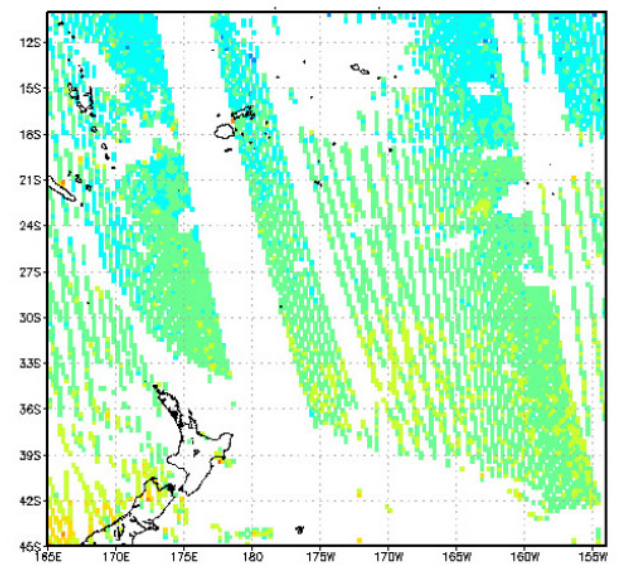

(b)
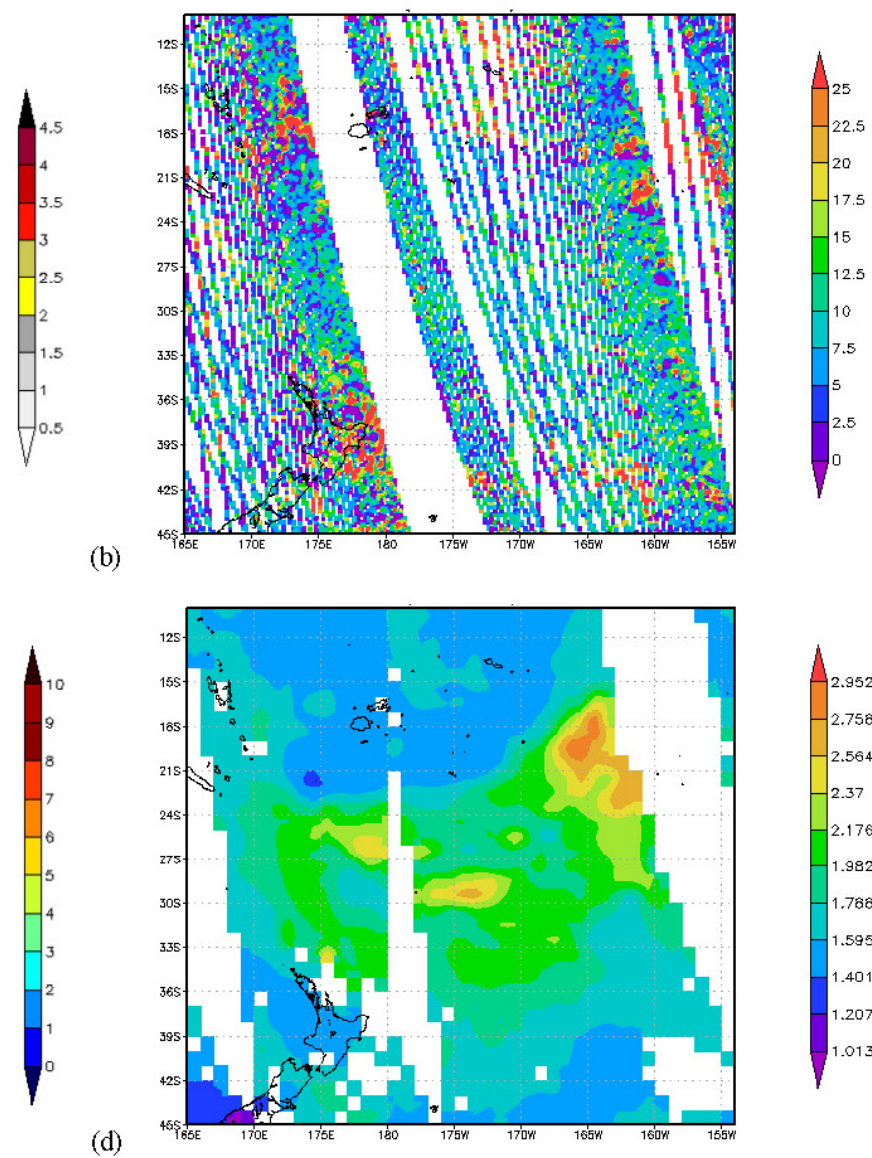

(d)

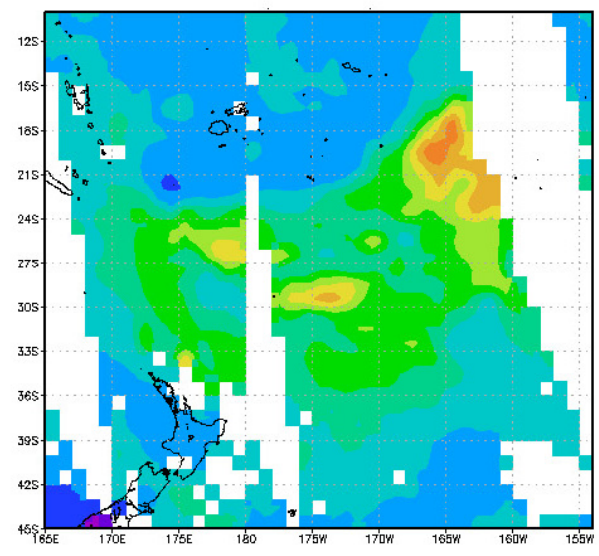

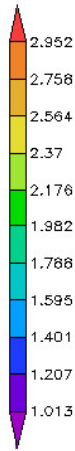

The time-series of $\mathrm{NO}_{2}$ to $\mathrm{CO}$ normalized excess mixing ratios shown in Figure 5(a) reveals a rapid decline with age in the Black Saturday smoke plume. $\mathrm{NO}_{2}$ declines with respect to $\mathrm{CO}$ from $0.004 \pm 0.001 \mathrm{~mol}_{\mathrm{mol}}^{-1}$ on 8 February over the active fire, to near background levels over Area 2 on 8 February and over the areas for 9 and 10 February when considering the levels of uncertainty. This decline is likely to be a symptom of the numerous destructive reactions that $\mathrm{NO}_{2}$ undergoes in the atmosphere, such as the oxidation of $\mathrm{NO}_{2}$ to form $\mathrm{HNO}_{3}, \mathrm{PAN}$ and other organic nitrates [46].

$\mathrm{H}_{2} \mathrm{CO}$ is released from the ground as a direct product of biomass burning but it has a lifetime of approximately three hours in daylight [45]. This is largely due to destruction by photolysis or reaction with the hydroxyl radical. To a lesser extent, $\mathrm{H}_{2} \mathrm{CO}$ reacts with $\mathrm{NO}_{3}$ resulting in abstraction of a hydrogen atom, aqueous conversion of $\mathrm{H}_{2} \mathrm{CO}$ results in formic acid and the addition of $\mathrm{HO}_{2}$ destroys $\mathrm{H}_{2} \mathrm{CO}$ and forms the hydroxyl methyl peroxy radical [46]. 
Figure 5. Normalized excess mixing ratios with respect to $\mathrm{CO}$ for (a) $\mathrm{NO}_{2}$ and (b) $\mathrm{H}_{2} \mathrm{CO}$ plotted as a time-series as the smoke ages from the youngest smoke measured over the active fire area on 8 February 2009 ( $\sim 4$ hours old) to the oldest smoke measured to the north of New Zealand on 10 February 2009 ( 60 hours old).
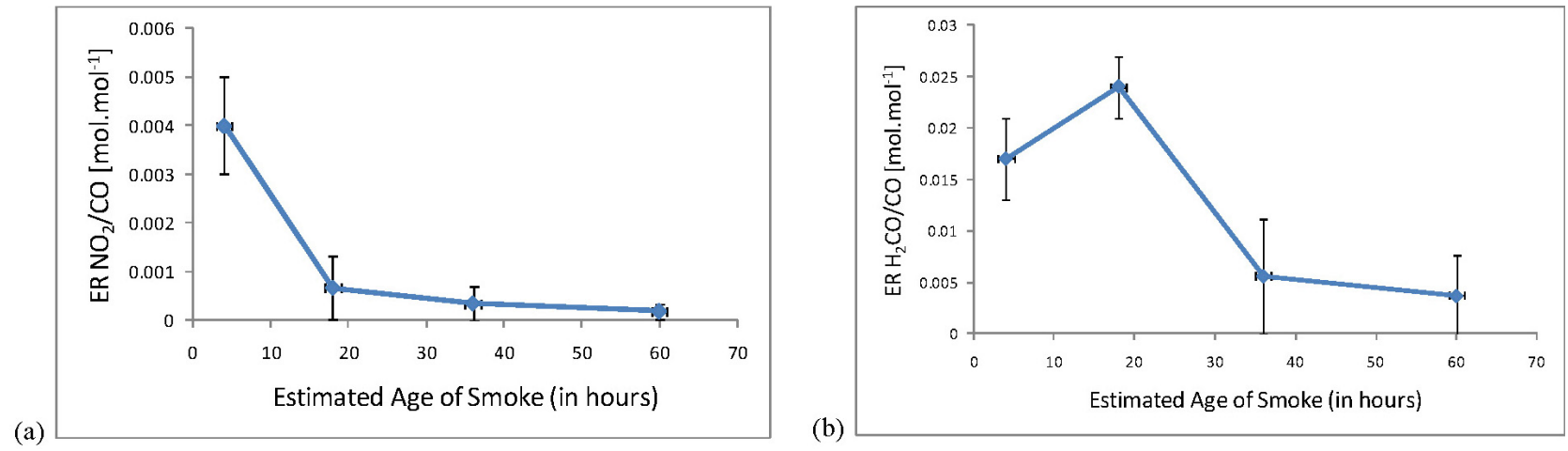

Based on its short lifetime as a consequence of destructive reactions, it could be expected that the ratio of $\mathrm{H}_{2} \mathrm{CO}$ to $\mathrm{CO}$ would appear highest on 8 February, particularly over the area of the active fires where the emissions were the freshest. Whilst the ratio of $\mathrm{H}_{2} \mathrm{CO}$ to $\mathrm{CO}$ was high over this area $\left(0.017 \pm 0.004 \mathrm{~mol}_{\mathrm{mol}}^{-1}\right)$, the relative amounts of $\mathrm{H}_{2} \mathrm{CO}$ were highest on 8 February over Area 2 (the $\mathrm{H}_{2} \mathrm{CO}$ to $\mathrm{CO}$ ratio was $0.024 \pm 0.003 \mathrm{~mol}^{\mathrm{mol}}{ }^{-1}$ ), where the smoke is slightly older, having travelled further from the site of the fires. The high uncertainties in the derivation of these ratios mean that the increase may not be statistically significant, however such an increase has been reported before in aged smoke [13] and could result from reactive sources of $\mathrm{H}_{2} \mathrm{CO}$ from within the plume itself. $\mathrm{H}_{2} \mathrm{CO}$ is a known product of the oxidation of many hydrocarbons that would be prominent in a smoke plume $[45,46]$. In particular, model studies have indicated that non methane volatile organic compounds (NMVOCs) such as acetic acid, methanol and ethene can be a significant secondary source of $\mathrm{H}_{2} \mathrm{CO}$ in smoke; these compounds are estimated to account for $43 \%$ of final $\mathrm{H}_{2} \mathrm{CO}$ production [48]. It is also possible that the larger $\mathrm{H}_{2} \mathrm{CO}$ to $\mathrm{CO}$ ratio calculated for the older part of the smoke plume on 8 February (area 2) resulted from a greater original emission ratio from the earlier stages of the active fires. This is plausible because the earliest fires would be expected to be dominated by flaming rather than smoldering combustion, and $\mathrm{CO}$ is associated more with smouldering phase whilst $\mathrm{H}_{2} \mathrm{CO}$ can be associated with both flaming and smoldering combustion [49].

The $\mathrm{H}_{2} \mathrm{CO}$ to $\mathrm{CO}$ ratios on 9 and 10 February reveal a subsequent decrease in the amount of $\mathrm{H}_{2} \mathrm{CO}$ within the plume as it ages. By these days the composition of $\mathrm{H}_{2} \mathrm{CO}$ had decreased to background levels within the respective uncertainties of the estimates, indicating that the excess $\mathrm{H}_{2} \mathrm{CO}$ from the fires and possible resultant reactions within the plume had disappeared.

\section{Conclusions}

We have presented emission ratios with respect to $\mathrm{CO}$ for the tropospheric ozone precursors $\mathrm{H}_{2} \mathrm{CO}$ and $\mathrm{NO}_{2}$ in smoke from the active fires that burned throughout Victoria, Australia during February 2009. The emission ratios were derived from total column amounts obtained from the satellite-based instruments $\mathrm{OMI}$ (for $\mathrm{H}_{2} \mathrm{CO}$ and $\mathrm{NO}_{2}$ ) and AIRS (for $\mathrm{CO}$ ). Mean emission ratios with respect to $\mathrm{CO}$ were determined for $\mathrm{H}_{2} \mathrm{CO}\left(0.016 \pm 0.004\right.$ mol.mol $\left.{ }^{-1}\right)$ and $\mathrm{NO}_{2}\left(0.005 \pm 0.002\right.$ mol.mol $\left.{ }^{-1}\right)$ within 
smoke from fires actively burning between 7 and 17 February 2009. The mean emission ratio for $\mathrm{H}_{2} \mathrm{CO}$ with respect to $\mathrm{CO}$ is in broad agreement with values previously quoted in the literature for temperate forest fires. The result for $\mathrm{NO}_{2}$ is especially significant because (to our knowledge) it is the first measurement of an emission ratio for this important gas from Australian forest fires.

OMI UV Aerosol Index has been used to track the smoke plume emitted from the Black Saturday firestorm on 7 February 2009. Comparison of the changing column amounts of $\mathrm{H}_{2} \mathrm{CO}$ and $\mathrm{NO}_{2}$ from OMI with CO columns from AIRS reveals information about the changing composition of the smoke plume as it ages. Large enhancements in all three of these trace gases were observed in the plume. $\mathrm{NO}_{2}$ column amounts exhibited a rapid decline with time, whilst $\mathrm{H}_{2} \mathrm{CO}$ column amounts peaked once the plume had begun to age, then declined and eventually dissipated after the third day. The apparent increase after aging (if statistically significant) could actually result from a larger emission ratio from the earlier stages of the active fires but also may be attributed to reactive sources of the trace gas from within the plume itself.

We found that OMI UV Aerosol Index was an excellent product for tracking smoke plumes and believe that this method could yield exciting new information on the chemical aging of smoke if applied to datasets from other satellite based sensors (such as IASI) which include longer lived species.

\section{Acknowledgments}

Analyses and visualizations used in this paper were produced with the Giovanni online data system, developed and maintained by the NASA Goddard Earth Sciences (GES) Data and Information Services Center (DISC). The authors gratefully acknowledge the OMI and AIRS mission scientists and Principal Investigators who provided the data used in this research effort, the extremely helpful comments of all referees and the Australian Research Council for funding this work as part of the project DP110101948. Preliminary results of this study were presented at the Australian Meteorological and Oceanographic Society meeting in Canberra in January 2010 and can be found in IOP Conference Series http://iopscience.iop.org/1755-1315/11/1/012023 [39].

\section{References and Notes}

1. Crutzen, P.J.; Andreae, M.O. Biomass burning in the tropics: Impact on atmospheric chemistry and biogeochemical cycles. Science 1990, 250, 1669-1678.

2. Crutzen, P.J.; Heidt, L.E.; Krasnec, J.P.; Hollock, W.H. Biomass burning as a source of atmospheric gases $\mathrm{CO}, \mathrm{H}_{2}, \mathrm{~N}_{2} \mathrm{O}, \mathrm{NO}, \mathrm{CH}_{3} \mathrm{Cl}$ and $\mathrm{COS}$. Nature 1979, 282, 253-256.

3. Wofsy, S.C. Interactions of $\mathrm{CH}_{4}$ and $\mathrm{CO}$ in the Earth's atmosphere. Ann. Rev. Earth Planet. Sci. 1976, 4, 441-469.

4. Wang, W.-C.;Yung, Y.L.; Lacis, A.A.; Mo, T.; Hansen, J.E. Greenhouse effects due to man-made perturbations of trace gases. Science 1976, 194, 685-690.

5. Lacaux, J.-P.; Delmas, R.A.; Cros, B.; Lefeivre, B.; Andreae, M.O. Influence of biomass burning emissions on precipitation chemistry in the equatorial forests of Africa. In Global Biomass Burning: Atmospheric, Climatic, and Biospheric Implications; Levine, J.S., Ed.; MIT Press: Cambridge, MA, USA, 1991; pp. 167-173. 
6. Meyer, C.P.; Luhar, A.K.; Mitchell, R.M. Biomass burning emissions over northern Australia constrained by aerosol measurements: I-Modelling the distribution of hourly emissions. Atmos. Environ. 2008, 42, 1629-1646.

7. Gregg, J.W.; Jones, C.G.; Dawson, T.E. Urbanization effects on tree growth in the vicinity of New York City. Nature 2003, 424, 183-187.

8. Palmer, P.I.; Jacob, D.J.; Fiore, A.M.; Martin, R.V.; Chance, K.; Kurosu, T.P. Mapping isoprene emissions over North America using formaldehyde column observations from space. J. Geophys. Res. Atmos. 2003, 108, doi:10.1029/2002JD002153.

9. Ito, A.; Penner, J.E. Global estimates of biomass burning emissions based on satellite imagery for the year 2000. J. Geophys. Res. 2004, 109, doi:10.1029/2003JD004423.

10. Hurst, D.F.; Griffith, D.W.T.; Carras, J.N.; Williams, D.J.; Fraser, P.J. Measurements of trace gases emitted by Australian savanna fires during the 1990 dry season. J. Atmos. Chem. 1994, 18, 33-56.

11. Shirai, T.; Blake, D.R.; Meinardi, S.; Rowland, F.S.; Russell-Smith, J.; Edwards, A.; Kondo, Y.; Koike, M.; Kita, K.; Machida, T.; et al. Emission estimates of selected volatile organic compounds from tropical savanna burning in northern Australia. J. Geophys. Res. 2003, 108, doi:10.1029/ 2001JD000841.

12. Hurst, D.F.; Griffith, D.W.T.; Cook, G.D. Trace gas emissions from biomass burning in tropical Australian savannas. J. Geophys. Res. 1994, 99, 16441-16456.

13. Paton-Walsh, C.; Deutscher, N.M.; Griffith, D.W.T.; Forgan, B.W.; Wilson, S.R.; Jones, N.B.; Edward, D.P. Trace gas emissions from savanna fires in northern Australia. J. Geophys. Res. Atmos. 2010, 115, doi:10.1029/2009JD013309.

14. Paton-Walsh, C.; Jones, N.; Wilson, S.; Meier, A.; Deutscher, N.; Griffith, D.; Mitchell, R.; Campbell, S. Trace gas emissions from biomass burning inferred from aerosol optical depth. Geophys. Res. Lett. 2004, 31, doi:10.1029/2003GL018973.

15. Paton-Walsh, C.; Jones, N.B.; Wilson, S.R.; Haverd, V.; Meier, A.; Griffith, D.W.T.; Rinsland, C.P. Measurements of trace gas emissions from Australian forest fires and correlations with coincident measurements of aerosol optical depth. J. Geophys. Res. Atmos. 2005, 110, doi:10.1029/2005JD006202.

16. Paton-Walsh, C.; Wilson, S.R.; Jones, N.B.; Griffith, D.W.T. Measurement of methanol emissions from Australian wildfires by ground-based solar Fourier transform spectroscopy. Geophys. Res. Lett. 2008, 35, doi:10.1029/2007GL032951.

17. Paton-Walsh, C.; Emmons, L.K.; Wilson, S.R. Estimated total emissions of trace gases from the Canberra Wildfires of 2003: A new method using satellite measurements of aerosol optical depth $\&$ the MOZART chemical transport model. Atmos. Chem. Phys. 2010, 10, 5739-5748.

18. Siddaway, J.M.; Petelina, S.V. Transport and evolution of the 2009 Australian Black Saturday bushfire smoke in the lower stratosphere observed by OSIRIS on Odin. J. Geophys. Res. Atmos. 2011, 116, doi:10.1029/2010JD015162.

19. Fromm, M.D. Satellite views of unprecedented smoke plume altitude and persistence after the 7 February 2009 Victoria pyrocumulonimbus storms. In Proceedings of the 2009 AGU Fall Meeting, San Francisco, CA, USA, 14-18 December 2009; abstract \#A51B-0115. 
20. National Aeronautics and Space Administration. Orbiting Carbon Observatory Launch. Available online: http://www.jpl.nasa.gov/news/press_kits/oco-launch.pdf (accessed on 11 November 2009).

21. Levelt, P.F.; Hilsenrath, E.; Leppelmeier, G.W.; Bhartia, P.K.; Tamminen, J.; de Haan, J.F.; Veefkind, J.P. Science objectives of the Ozone Monitoring Instrument. IEEE Trans. Geosci. Remote Sens. 2006, 44, 1199-1208.

22. Levelt, P.F.; Dobber, M.R.; Mälkki, A.; Visser, H.; de Vries, J.; Stammes, P.; Lundell, J.O.V.; Saari, H. The ozone monitoring instrument. IEEE Trans. Geosci. Remote Sens. 2006, 44, 1093-1101.

23. Boeke, N.L.; Marshall, J.D.; Alvarez, S.; Chance, K.V.; Fried, A.; Kurosu, T.P.; Rappenglück, B.; Richter, D.; Walega, J.; Weibring, P.; et al. Formaldehyde columns from the Ozone Monitoring Instrument: Urban versus background levels and evaluation using aircraft data and a global model. J. Geophys. Res. Atmos. 2011, 116, doi:10.1029/2010JD014870.

24. Celarier, E.A.; Brinksma, E.J.; Gleason, J.F.; Veefkind, J.P.; Cede, A.; Herman, J.R.; Ionov, D.; Goutail, F.; Pommereau, J.-P.; Lambert, J.-C.; et al. Validation of ozone monitoring instrument nitrogen dioxide columns. J. Geophys. Res. Atmos. 2008, 113, doi:10.1029/2007JD008908.

25. Russell, A.R.; Perring, A.E.; Valin, L.C.; Bucsela, E.J.; Browne, E.C.; Min, K.E.; Wooldridge, P.J.; Cohen, R.C. A high spatial resolution retrieval of $\mathrm{NO}(2)$ column densities from OMI: Method and evaluation. Atmos. Chem. Phys. 2011, 11, 8543-8554.

26. Torres, O.; Tanskanen, A.; Veihelmann, B.; Ahn, C.; Braak, R.; Bhartia, P.K.; Veefkind, P.; Levelt, P. Aerosols and surface UV products from Ozone monitoring instrument observations: An overview. J. Geophys. Res. Atmos. 2007, 112, doi:10.1029/2007JD008809.

27. Chahine, M.T.; Pagano, T.S.; Aumann, H.H.; Atlas, R.; Barnet, C.; Blaisdell, J.; Chen, L.; Divakarla, M.; Fetzer, E.J.; Goldberg, M.; et al. Improving weather forecasting and providing new data on greenhouse gases. Bull. Am. Meteorol. Soc. 2006, 87, 911-926.

28. McMillan, W.W.; Barnet, C.; Strow, L.; Chahine, M.T.; McCourt, M.L.; Warner, J.X.; Novelli, P.C.; Korontzi, S.; Maddy, E.S.; Datta, S. Daily global maps of carbon monoxide from NASA's Atmospheric Infrared Sounder. Geophys. Res. Lett. 2005, 32, doi:10.1029/2004GL021821.

29. Fu, T.M.; Jacob, D.J.; Palmer, P.I.; Chance, K.; Wang, Y.X.X.; Barletta, B.; Blake, D.R.; Stanton, J.C.; Pilling, M.J. Space-based formaldehyde measurements as constraints on volatile organic compound emissions in east and south Asia and implications for ozone. J. Geophys. Res. Atmos. 2007, 112, doi:10.1029/2006JD007853.

30. Millet, D.B.; Jacob, D.J.; Boersma, K.F.; Fu, T.M.; Kurosu, T.P.; Chance, K.; Heald, C.L.; Guenther, A. Spatial distribution of isoprene emissions from North America derived from formaldehyde column measurements by the OMI satellite sensor. J. Geophys. Res. Atmos. 2008, 113, doi:10.1029/2007JD008950.

31. Pfister, G.; Hess, P.G.; Emmons, L.K.; Lamarque, J.F.; Wiedinmyer, C.; Edwards, D.P.; Petron, G.; Gille, J.C.; Sachse, G.W. Quantifying CO emissions from the 2004 Alaskan wildfires using MOPITT CO data. Geophys. Res. Lett. 2005, 32, doi:10.1029/2005GL022995. 
32. Fisher, J.A.; Jacob, D.J.; Purdy, M.T.; Kopacz, M.; Le Sager, P.; Carouge, C.; Holmes, C.D.; Yantosca, R.M.; Batchelor, R.L.; Strong, K.; et al. Source attribution and interannual variability of Arctic pollution in spring constrained by aircraft (ARCTAS, ARCPAC) and satellite (AIRS) observations of carbon monoxide. Atmos. Chem. Phys. 2010, 10, 977-996.

33. Kopacz, M.; Jacob, D.J.; Fisher, J.A.; Logan, J.A.; Zhang, L.; Megretskaia, I.A.; Yantosca, R.M.; Singh, K.; Henze, D.K.; Burrows, J.P.; et al. Global estimates of CO sources with high resolution by adjoint inversion of multiple satellite datasets (MOPITT, AIRS, SCIAMACHY, TES). Atmos. Chem. Phys. 2010, 10, 855-876.

34. Mebust, A.K.; Russell, A.R.; Hudman, R.C.; Valin, L.C.; Cohen, R.C. Characterization of wildfire $\mathrm{NO}(\mathrm{x})$ emissions using MODIS fire radiative power and OMI tropospheric $\mathrm{NO}(2)$ columns. Atmos. Chem. Phys. 2011, 11, 5839-5851.

35. NASA Goddard Earth Sciences Data and Information Services Centre (NASA GES DISC). Giovanni Online Data System. Available online: http://disc.sci.gsfc.nasa.gov.giovanni (accessed on 3 August 2009).

36. Kaufman, Y.J.; Justice, C.O.; Flynn, L.P.; Kendall, J.D.; Prins, E.M.; Giglio, L.; Ward, D.E.; Menzel, W.P.; Setzer, A.W. Potential global fire monitoring from EOS-MODIS. J. Geophys. Res. Atmos. 1998, 103, 32215-32238.

37. Boersma, F.; Bucsela, E.; Brinksma, E.; Gleason, J.F. $\mathrm{NO}_{2}$, in OMI Algorithm Theoretical Basis Document Volume IV: OMI Trace Gas Algorithms; Chance, K., Ed.; Smithsonian Astrophysical Observatory: Cambridge, MA, USA, 2002; pp. 13-36.

38. Chance, K.; Kurosu, T.P.; Rothman, L.S. HCHO, in OMI Algorithm Theoretical Basis Document Volume IV: OMI Trace Gas Algorithms; Chance, K., Ed.; Smithsonian Astrophysical Observatory: Cambridge, MA, USA, 2002; pp. 37-47.

39. Young, E.L.; Paton-Walsh, C. Formaldehyde and nitrogen dioxide in smoke plumes from Australia's Black Saturday fires. IOP Conf. Ser. 2010, 11, doi:10.1088/1755-1315/11/1/012023.

40. Andreae, M.O.; Merlet, P. Emission of trace gases and aerosols from biomass burning. Glob. Biogeochem. Cycles 2001, 15, 955-966.

41. Akagi, S.K.; Yokelson, R.J.; Wiedinmyer, C.; Alvarado, M.J.; Reid, J.S.; Karl, T.; Crounse, J.D.; Wennberg, P.O. Emission factors for open and domestic biomass burning for use in atmospheric models. Atmos. Chem. Phys. 2011, 11, 4039-4072.

42. Alvarado, M.J.; Prinn, R.G. Formation of ozone and growth of aerosols in young smoke plumes from biomass burning: 1. Lagrangian parcel studies. J. Geophys. Res. Atmos. 2009, 114, doi:10.1029/2008JD011144.

43. Laursen, K.K.; Hobbs, P.V.; Radke, L.F.; Rasmussen, R.A. Some trace gas emissions from northamerican biomass fires with an assessment of regional and global fluxes from biomass burning. $J$. Geophys. Res. Atmos. 1992, 97, 20687-20701.

44. Alvarado, M.J.; Logan, J.A.; Mao, J.; Apel, E.; Riemer, D.; Blake, D.; Cohen, R.C.; Min, K.E.; Perring, A.E.; Browne, E.C.; et al. Nitrogen oxides and PAN in plumes from boreal fires during ARCTAS-B and their impact on ozone: An integrated analysis of aircraft and satellite observations. Atmos. Chem. Phys. 2010, 10, 9739-9760.

45. Warneck, P. Chemistry of the Natural Atmosphere; Academic Press Inc: London, UK, 1988; Volume 41. 
46. Atmospheric Chemistry and Global Change; Brasseur, G.P., Orlando, J.J., Tyndall, G.S., Eds.; Oxford University Press: New York, NY, USA, 1999.

47. The British Atmospheric Data Centre. http://badc.nerc.ac.uk/home/index.html (accessed on 4 September 2009).

48. Stavrakou, T.; Müller, J.F.; De Smedt, I.; Van Roozendael, M.; van der Werf, G.R.; Giglio, L.; Guenther, A. Evaluating the performance of pyrogenic and biogenic emission inventories against one decade of space-based formaldehyde columns. Atmos. Chem. Phys. 2009, 9, 1037-1060.

49. Yokelson, R.J.; Griffith, D.W.T.; Ward, D.E. Open-path Fourier transform infrared studies of large-scale laboratory biomass fires. J. Geophys. Res. 1996, 101, 21067-21080.

(C) 2011 by the authors; licensee MDPI, Basel, Switzerland. This article is an open access article distributed under the terms and conditions of the Creative Commons Attribution license (http://creativecommons.org/licenses/by/3.0/). 